Sains Malaysiana 50(4)(2021): 1211-1220

http://doi.org/10.17576/jsm-2021-5005-02

\title{
Age-Related Testosterone Changes and Corresponding Song Patterns in Red- whiskered Bulbul (Pycnonotus jocosus Linnaeus, 1758)
}

(Perubahan Testosteron Berkait-Umur dan Pola Lagu Sepadan bagi Merbah Berjambang Merah (Pycnonotus jocosus Linnaeus, 1758))

\section{PANAS TUmKIRATIWONG, DARIKA MANATHAMKAMON, RATTANAWAT CHAIYARAT \& KAN KHOOMSAB*}

\begin{abstract}
We monitored total testosterone profiles and song patterns of 12 males and 2 females Red-whiskered Bulbuls (Pycnonotus jocosus), aged 5-10 months. Each bird was maintained in a cage sized of $38 \times 38 \times 50 \mathrm{~cm}$ and raised in a $22{ }^{\circ} \mathrm{C}$-controlled room-sized of $6 \times 10 \times 3.5 \mathrm{~m}$. The song prototype was played during 0700-11.00 h, with an amplifierconnected loudspeaker placed at the center and the song was recorded during both 1100-1200 and 1300-1500 h, and then their sonograms were analyzed with Avisoft SAS Lab Pro, version 4.3. Feces were collected monthly and immediately following recording their songs to determine male and female total testosterone levels by radioimmunoassay. The results demonstrated that an average of a frequency that the male and the female birds produced was $4.27 \pm 0.13 \mathrm{kHz}$ with a frequency range of $1.50-5.18 \mathrm{kHz}$. The males aged 8-10 months old produced songs with an average of 25.83 syllables $/ 10 \mathrm{~s}$, similar to those found in the song prototype while the females produced those with an average of 18.33 syllables/10 s. The males produced songs consisting of more syllables and fewer intervals than those of the females. The coefficient of correlations between the mean total testosterone levels with the syllables/10 s and intervals/10 s were +0.68 and -0.69 , respectively. Additionally, the male Red-whiskered Bulbuls created the complicated and various song types that corresponded well with the marked increases in the total testosterone levels at the age of 8 to 10 months old.
\end{abstract}

Keywords: Phrase; red-whiskered Bulbul; song type, syllable; total testosterone

\section{ABSTRAK}

Kami memantau jumlah profil testosteron dan pola lagu bagi 12 ekor burung jantan dan 2 ekor burung betina Merbah berjambang merah (Pycnonotus jocosus), berumur 5-10 bulan. Setiap burung diletakkan di dalam sangkar berukuran $38 \times 38 \times 50 \mathrm{~cm}$ dan dibesarkan di dalam bilik bersuhu $22{ }^{\circ} \mathrm{C}$ berukuran $6 \times 10 \times 3.5 \mathrm{~m}$. Prototip lagu dimainkan pada waktu 0700-1100 jam dengan pembesar suara yang disambungkan kepada amplifier yang diletakkan di tengah dan lagu tersebut dirakam selama 1100-1200 dan 1300-1500 jam, kemudian rakaman sonogram dianalisis dengan menggunakan Avisoft SAS Lab Pro, versi 4.3. Najis burung juga dikumpulkan segera bagi setiap bulan berdasarkan rakaman lagu-lagu mereka untuk menentukan jumlah tahap testosteron jantan dan betina melalui radioimunoasai. Hasil kajian menunjukkan bahawa rata-rata frekuensi yang dihasilkan bagi burung jantan dan betina adalah $4.27 \pm 0.13$ $\mathrm{kHz}$ dengan julat frekuensi 1.50-5.18 kHz. Burung jantan berusia 8-10 bulan menghasilkan lagu dengan rata-rata 25.83 suku kata/10 s, serupa dengan prototip lagu sementara burung betina menghasilkan lagu dengan rata-rata 18.33 suku kata/10 s. Burung jantan menghasilkan lagu dengan lebih banyak suku kata tetapi selang waktu yang lebih sedikit berbanding burung betina. Pekali korelasi antara tahap keseluruhan testosteron dengan suku kata/10 s dan selang/10 s masing-masing adalah +0.68 dan -0.69. Selain itu, burung Merbah jantan berjambang merah menghasilkan jenis lagu yang rumit dan pelbagai yang sesuai dengan peningkatan ketara dalam tahap testosteron pada usia 8 hingga 10 bulan.

Kata kunci: Frasa; jenis lagu; jumlah testosteron; Merbah berjambang merah; suku kata

\section{INTRODUCTION}

The Red-whiskered Bulbul (Pycnonotus jocosus) of the Pycnonotidae Family is also known as many different names in Thailand, namely the Red-whiskered Bulbul, the
Spotted Bird in the southern region, the Spotted Bulbul in the central region, and the Peach Willow in the northern region (Khananurak 2006). The Red-whiskered Bulbul 
sings throughout the year and the female bird can sing but has fewer phrases of the song than those of the male one.

Bird song is a form of complex communication that is both innate (Catchpole 1979) and learned (Jarvis 2004). It may be sent either as a long and complex, or a short and uncomplicated signal (Catchpole \& Slater 1995) which is considered as one of the greatest evolution of vocal communication (Sitasuwan 1993). The behavior of learning a song often has a specific period, for example, in the Zebra Finch (Taeniopygia guttata), it occurs only in the first few years of life and the song learning behavior cannot occur when young birds become adults (Marler \& Peter 1987). However, some birds can learn a song even as adults and can develop the phrases every year in the reproductive season, such as the Canary (Serinus canaria) (Bohner et al. 1990; Brenowitz et al. 1997). Marler (1997) stated that song learning behavior is one step that leads to the development of the song phrase. The young bird will recognize the song phrases of the adult bird of the same species in the following steps: step 1, the young bird memorizes acquisition; step 2, the young bird practices singing a memorable song or imitating the adult, and step 3, the young bird produces various vocals by creating a variety of phrases. In the future, they will develop vocals to be unique with an improved sound structure. The development of a song will not occur if the young bird does not hear the sound either from the intraspecific adult or from tape recordings (Brenowitz et al. 1997). The development of brain neural networks helps birds to recognize singing with complexity and plasticity (Bottjer \& Johnson 1997; Schlinger 1997). There is a positive relationship between a song syllable and plasma testosterone levels in male Barn Swallows (Hirundo rustica) (Galeotti et al. 1997). However, no data on the influence of the male hormones, androgens, controlling the song in the Red-whiskered Bulbul is available. Therefore, this study focuses on the age range of learning behavior of the singing in the male and female Red-whiskered Bulbuls in corresponding to changes in total testosterone levels. The study on the development of song patterns in each appropriate age range of the Red-whiskered Bulbul will provide basic information on the learning behavior of the singing that imitated from its song prototype.

\section{Materials AND Methods}

\section{ANIMAL HUSBANDRY}

Fourteen Red-whiskered Bulbuls aged 4 months (Figure 1 left), were purchased from a private farm in Nonthaburi province, Thailand. Each Red-whiskered Bulbul kept in a cage was identified by placing three color-banded rings above the male's left and female's right tarsus joint and raised for an additional 6 months. Individual birds were kept in a cage with a size of $38 \times 38 \times 50 \mathrm{~cm}$. The foods providing to the Red-whiskered Bulbuls consisted of fruits such as papaya and bananas, a pellet diet of 3-6 weekaged broiler, bird worms, and multivitamin supplementsmixed water. The water and food were changed every day and given ad libitum. They were raised in a room with a size of $6 \times 10 \times 3.5 \mathrm{~m}$. The room temperature was approximate $22{ }^{\circ} \mathrm{C}$ with light-dark photoperiod of $12: 12 \mathrm{~h}$. Their cages were placed in a circle around the central amplifier with 3 $\mathrm{m}$ away from the speaker and $80 \mathrm{~cm}$ in between each cage (Figure 1 right). They were sunbathed for an hour from 0900-1000 h, every other day.
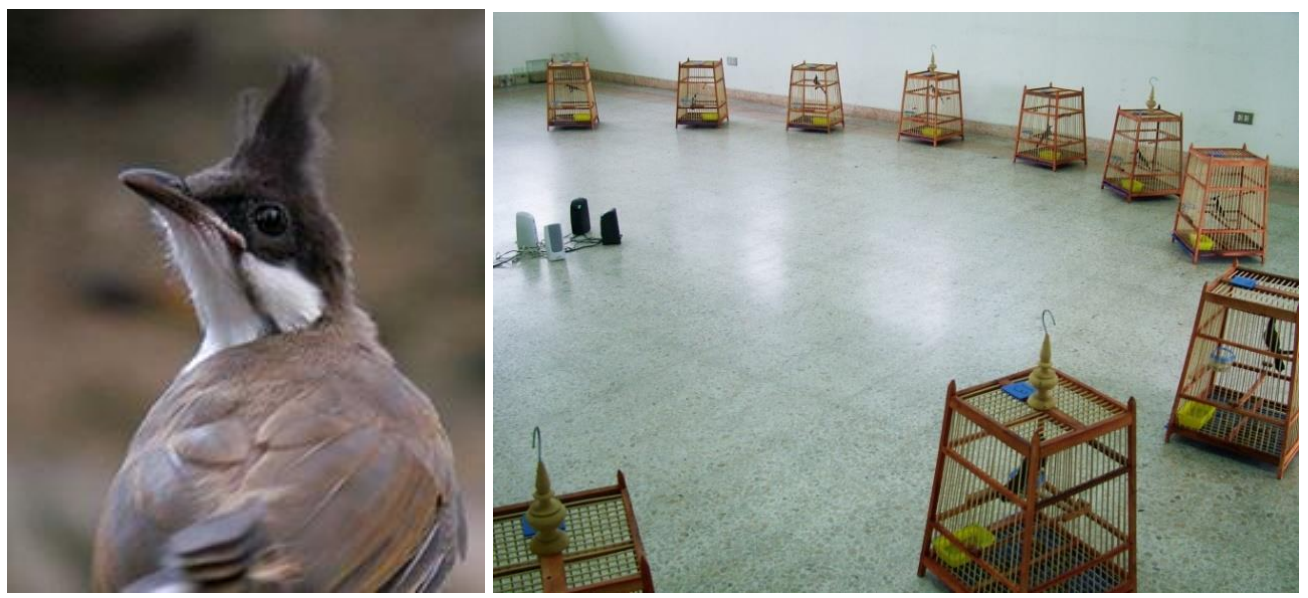

FIGURE 1. Left, Red-whiskered Bulbul (Pycnonotus jocosus), aged 4 months; Right, location of placing 14 cages of the Red-whiskered Bulbuls in a sound recording room 


\section{SEXING OF THE RED-WHISKERED BULBUL}

Gender identification of the Red-whiskered Bulbul based on its morphology is difficult. Therefore, gender was identified by monitoring its sex chromosome as follows: sexing 14 Red-whiskered Bulbuls was conducted by extracting DNA from their wing root tissues by using QIAamp DNA Mini Kit to monitor the purity of DNA samples by measuring absorbance at a wavelength between 260 and $280 \mathrm{~nm}$, then followed by the polymerase chain reaction (PCR). DNA was produced using a $5 \%$ agarose gel stained with ethidium bromide (Griffiths \& Tiwari 1995). We found one band and two bands in twelve male and two female birds, respectively. This method is based on the binding principle of a primer on the CHD gene of poultry (CHDC and CHDW). After using primers p2 and p8 to grasp both genes, they will get the axons and intron with different lengths (Griffiths \& Tiwari 1995). Based on the examination of the PCR products of male and female birds, one band of PCR (CHDC) and two bands of PCR bands (CHDW) were identified as male and female birds, respectively.

SONG TYPE OF THE MALE AND FEMALE REDWHISKERED BULBULS, AGED FROM 5 TO 10 MONTHS

The components of the song pattern, including the number of phrases, the number of syllables, and the interval between phrases in both male and female Red-whiskered Bulbuls aged 5, 6, 7, 8, 9, and 10 months were monitored.

\section{SONG PROTOTYPE}

Brenowitz et al. (1997) defined the acoustic structure of a bird song as follows: The simplest individual sound is referred to as elements or notes. A series of one or more elements that occur together in a regular pattern in a song is referred to as a syllable. A sequence of one or more syllables that occurs repeatedly is described equivalently as either a song phrase or a motif. A particular combination of phrases or motifs that occurs repeatedly constitutes a song type. Finally, a sequence of one or more phrases separated from other phrase sequences by silent intervals of variable duration is a song bout.

The song prototype was a song recorded from the adult Red-whiskered Bulbul with a frequency range of 2-5 kHz. It consists of 5 phrases with 5-13 syllables/phrase within $10 \mathrm{~s}$. There were 37 syllables/10 s of recording time, with phrase $1(\mathrm{P} 1)$ and phrase $2(\mathrm{P} 2)$ having similar syllables (Figure 2). We turned on the song prototype to all fourteen Red-whiskered Bulbuls during 0700-1100 h, every day throughout the experimental period.

\section{SONG RECORDING}

We recorded monthly the singing of all fourteen Redwhiskered Bulbuls for $2 \mathrm{~h}$ during both 1100-1200 and 1300-1500 h, for 6 months by using the Sony ICD-BM1 voice recorder. Songs were produced by each Redwhiskered Bulbul as a sonogram format with the program Avisoft SAS Lab Pro version 4.3 for analysis of sound frequency, number of phrases, number of syllables, and the interval between phrases.

MODEL

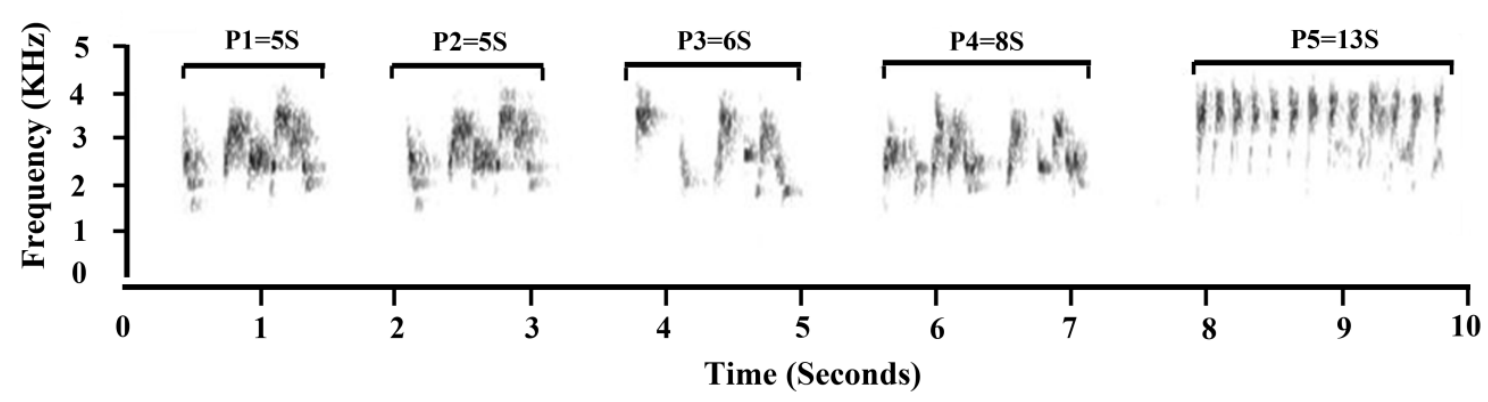

FIGURE 2. Sonogram of a song prototype of adult Red-whiskered Bulbul (Pycnonotus jocosus)

Notes: Hz, Frequencies (times/s); P, phrases, and S, syllables 


\section{DETERMINATION OF MALE AND FEMALE TOTAL TESTOSTERONE LEVELS OF THE RED-WHISKERED BULBULS, AGED FROM 5 TO 10 MONTHS}

We measured the levels of total testosterone from feces in both male and female Red-whiskered Bulbuls at the age of 5, 6, 7, 8, 9, and 10 months. The methods of fecal collection and total testosterone determination were as follows:

\section{FRESH FECAL COLLECTION AND FECAL EXTRACTS FOR SEX HORMONE DETERMINATION}

Samples of fresh feces were collected monthly and immediately after recording song of each Red-whiskered Bulbuls for 6 months. A sample consisted of four droppings. Each sample was kept in a vacuum plastic bag, frozen in an icebox-inside container, and preserved at $-80{ }^{\circ} \mathrm{C}$ for further sex hormone analysis. The procedure for the preparation of the fecal samples for sex hormones determination followed a modified method of Cockrem and Rounce (1995). A frozen sample was left at room temperature and dried at $55{ }^{\circ} \mathrm{C}$ in an oven overnight. A dried sample was weighed for 10 to $30 \mathrm{~g}$ and added with phosphate-buffered saline with gelatin, $\mathrm{pH} 7.4$ in a ratio of 1:8 $(\mathrm{g} / \mathrm{mL})$. The mixed sample was thoroughly stirred with a glass rod and left overnight at $4{ }^{\circ} \mathrm{C}$ in a refrigerator. On the next day, the solution was centrifuged at $6,000 \mathrm{~g}$ for $10 \mathrm{~min}$. The upper phase was aspirated without disturbing the interface. A $500 \mu \mathrm{L}$ sample was added to $5.0 \mathrm{~mL}$ of dichloromethane for the extraction of total testosterone in a screw-top glass extraction tube. The mixture was then capped and mixed for $5 \mathrm{~min}$ by gentle inversion with an end-over-end rotator, and then centrifuged for $5 \mathrm{~min}$ at $1,500 \mathrm{~g}$ to separate the layers. The upper phase was aspirated without disturbing the interface. Then, $2.0 \mathrm{~mL}$ of the lower phase was transferred to a clean $12 \mathrm{~mm} \times 75$ $\mathrm{mm}$ glass tube and evaporated to dryness under a gentle stream of nitrogen at $37^{\circ} \mathrm{C}$. The dried extracts of male and female feces were reconstituted with $200 \mathrm{~mL}$ of the total testosterone buffers. The levels of total testosterone were measured using the ${ }^{125} \mathrm{I}$ radioimmunoassay (RIA).

\section{ANALYSIS OF FECAL TOTAL TESTOSTERONE}

Total testosterone determination was performed using a Testosterone RIA CT Kit (RADIM S.p.A., Via del Mare, 125-00040 Pomezia, Roma, Italia). The intra-assay (repeatability) and inter-assay (reproducibility) variability expressed as coefficients of variation $(\% \mathrm{CV})$ were 1.5-6.1 and 7.8-9.3\%, respectively. The approximate sensitivity of this assay was $0.017 \mathrm{ng} / \mathrm{mL}$. The crossreactions were $100 \%$ with testosterone, $5.6 \%$ with 5 - $\alpha$-dihydrotestosterone, $3.8 \%$ with $1,(5 \alpha)$-androstane$17-\beta$-ol-3one, $2.6 \%$ with 19 -hydroxyandrostenedione, $1.6 \%$ with androstenedione, and lower than $0.1 \%$ with androstenediol, danazol, estrone, dehydroepiandrosteronesulfate, estradiol, 5- $\alpha$-androstane-3- $\alpha$-ol-17one and 5 - $\beta$-androstane-17- $\alpha$-ol-3one. The spiking recovery values averaged $92.4-97.4 \%$. The parallelisms of undiluted concentration $(4.30 \mathrm{ng} / \mathrm{mL})$ with $50.0,25.0,12.5$, and $6.25 \%$ dilution of its diluted concentrations were 2.25 , $1.21,0.63$, and $0.28 \mathrm{ng} / \mathrm{mL}$, respectively. Radioactivity was measured with a gamma counter and total testosterone concentrations were calculated with GMS Program version 3.05 Gamma-C12.

\section{STATISTICAL ANALYSIS}

All data were expressed as means \pm standard deviations. Shapiro-Wilk test and Levene's test were used to determine whether the data were normally distributed and homogeneity of variances or not, respectively. Since all data were non-normal distribution, non-homogeneity of variance, and repeated measurement, the Friedman test was used to test the differences in the number of syllables/10 s, intervals between phrases, total testosterone over six months, and subsequently, the Wilcoxon signedrank test as post hoc tests was employed to compare the differences in the number of syllables/10 s, intervals between phrases, and total testosterone between every two months (month to month). Furthermore, Spearman's correlation coefficient was used to determine the relationships between total testosterone and number of syllables/10 s, time intervals/10 s. The level of significance was set to $p<0.05$ for all parameters with SPSS version 20 .

\section{RESULTS}

\section{SONG PATTERNS OF MALE AND FEMALE RED- WHISKERED BULBULS, AGED 5-10 MONTHS}

The song that all fourteen Red-whiskered Bulbuls produced had a frequency range of $1.50-5.18 \mathrm{kHz}$ (mean $\pm \mathrm{SD}=4.27 \pm 0.13$ ). Generally, the Red-whiskered Bulbuls aged $5,6,7,8,9$, and 10 months old created 1 syllable/ phrase with $13,6,5,1,1$, and 1 patterns, respectively; 2 syllables/phrase with $8,5,6,4,5$, and 3 patterns of a phrase, respectively; 3 syllables/phrase with $2,3,2,3,4$, and 4 patterns, respectively; 4 syllables/phrase with 1, 3, 5, 7, 7 , and 6 patterns, respectively; 5 syllables/phrase with 0,0 , 
1, 2, 2, and 4 patterns, respectively; and 6 syllables/phrase with $0,1,1,1,3$, and 3 patterns, respectively. The male Red-whiskered Bulbuls aged 5, 6, 7, 8, 9, and 10 months produced differently in song characteristics including time/ phrase, syllable/phrase, phrase/10 s, syllable/10 s, and interval/10 s (Table 1).

The male Red-whiskered Bulbuls aged 5, 6, 7, 8, 9 , and 10 months showed song patterns of time/phrase, syllables/phrase, and phrases/10 $\mathrm{s}$ as following (mean \pm SD): $0.21 \pm 0.12 \mathrm{~s}, 2.47 \pm 0.54$ syllables, and $1.67 \pm$ 0.65 phrases, respectively; $0.39 \pm 0.20 \mathrm{~s}, 3.16 \pm 0.96$ syllables, and $3.58 \pm 1.24$ phrases, respectively; $0.44 \pm$ $0.20 \mathrm{~s}, 3.04 \pm 0.95$ syllables, and $3.75 \pm 1.05$ phrases, respectively; $0.55 \pm 0.16 \mathrm{~s}, 3.52 \pm 0.78$ syllables, and $5.25 \pm 0.62$ phrases, respectively; $0.65 \pm 0.19 \mathrm{~s}, 4.03 \pm$ 0.98 syllables, and $5.58 \pm 0.67$ phrases, respectively; 0.74 $\pm 0.21 \mathrm{~s}, 4.37 \pm 0.97$ syllables, and $5.92 \pm 0.29$ phrases, respectively. The female Red-whiskered Bulbuls aged 5, $6,7,8,9$, and 10 months showed song patterns of time/ phrase, syllables/phrase, and phrases/10 s (mean \pm SD) as following: $0.20 \pm 0.10 \mathrm{~s}, 2.00 \pm 0.00$ syllables, and no phrase, respectively; $0.25 \pm 0.13,2.36 \pm 0.67$ syllables, and $1.00 \pm 1.00$ phrase, respectively; $0.29 \pm 0.12 \mathrm{~s}, 2.40 \pm$ 0.73 syllables, and $1.33 \pm 0.57$ phrases, respectively; 0.37 $\pm 0.13 \mathrm{~s}, 2.89 \pm 0.90$ syllables, and $3.33 \pm 0.57$ phrases, respectively; $0.36 \pm 0.14 \mathrm{~s}, 2.88 \pm 0.80$ syllables, and 3.33 \pm 0.57 phrases, respectively, $0.43 \pm 0.16 \mathrm{~s}, 3.12 \pm 0.78$ syllables, and $4.33 \pm 0.57$ phrases, respectively (Table 1). Therefore, the averages of time/phrase, syllables/ phrase, and phrases/10 s were gradually increased with the advancing age of the male and female Red-whisker Bulbuls. However, such the song characteristics created by the female were less than that of the male at the same age of every age range.

The results indicated that the number of syllables/10 $\mathrm{s}$ of the male was greater than that of the female. The average numbers of syllables/10 s of the male aged 5, 6, $7,8,9$ and 10 months were $15.33 \pm 0.93,17.92 \pm 0.96$, $19.25 \pm 0.52,21.75 \pm 0.56,23.83 \pm 1.01$, and $25.83 \pm 1.02$, respectively, while as the average number of syllables $/ 10 \mathrm{~s}$ of the female aged 5, 6, 7, 8, 9 and 10 months were 12.00 $\pm 2.00,13.00 \pm 1.73,13.67 \pm 1.53,17.33 \pm 1.53,16.33$ \pm 1.15 , and $18.33 \pm 0.57$, respectively. The mean rank of numbers of syllables $/ 10 \mathrm{~s}$ of the male were significantly different (Friedman test, $\chi^{2}=50.478, p=0.000$ ) among age groups. A comparison between each of two age group (Wilcoxon signed-rank test) were as followings: the 5vs. 6-month old was insignificantly different $(\mathrm{z}=-1.848$, $\mathrm{p}=0.065)$, and the 5- vs. 7-, 5- vs. 8-, 5-vs. 9-, and 5- vs. 10-month-old were significantly different $(\mathrm{z}=-2.633, \mathrm{p}=$ $0.008 ; \mathrm{z}=-3.078, \mathrm{p}=0.002 ; \mathrm{z}=-3.066, \mathrm{p}=0.002$; and $\mathrm{z}=-3.063, \mathrm{p}=0.002$, respectively). The 6- vs. 7-month old was insignificantly different $(\mathrm{z}=-1.615, \mathrm{p}=0.106)$; the 6- vs. 8-, 6- vs. 9-, and the 6- vs. 10-month old were significantly different $(z=-2.694, p=0.007 ; z=-3.074, p$ $=0.002$; and $z=-3.066, p=0.002$, respectively). The 7-vs. 8-, 7- vs. 9-, and 7- vs. 10-month old were significantly different $(\mathrm{z}=-2.662, \mathrm{p}=0.008 ; \mathrm{z}=-2.927,0.003$; and $\mathrm{z}=$ $-3.068, p=0.002$, respectively). The 8-vs. 9-, and 8-vs. 10 -month old were significantly different $(\mathrm{z}=-2.504, \mathrm{p}=$ 0.012 ; and $\mathrm{z}=-3.070, \mathrm{p}=0.002$, respectively). The 9- vs. 10 - month old was significantly different $(\mathrm{z}=-2.848, \mathrm{p}=$ 0.004) (Table 1).

The average number of syllables/10 s of male and female Red-whiskered Bulbuls increased with the advancing age. However, the average number of syllables/10 s of the female was less than that of the male at the same age at every age range. The average number of syllables/10 s had gradually improved and was stable at the age of 8-10 months old.

It is found that the averages of intervals $/ 10 \mathrm{~s}$ of the male Red-whiskered Bulbul aged 5, 6, 7, 8, 9, and 10 months were $7.00 \pm 0.09,6.37 \pm 0.12,6.16 \pm 0.13,5.76$ $\pm 0.12,5.31 \pm 0.18$ and $4.81 \pm 0.22 \mathrm{~s} / 10 \mathrm{~s}$, respectively, while as those of the female Red-whiskered Bulbul at aged $5,6,7,8,9$, and 10 months were $7.42 \pm 0.14,7.21$ $\pm 0.20,7.21 \pm 0.13,6.83 \pm 0.12,6.59 \pm 0.23$ and $6.45 \pm$ $0.18 \mathrm{~s} / 10 \mathrm{~s}$, respectively. The mean rank of interval/10 s of the male were significantly different among age groups (Friedman test, $\chi^{2}=57.857, \mathrm{p}=0.000$ ). A comparison between each two age group (Wilcoxon signed-rank test) was as following: the 5- vs. 6-, 5- vs. 7-, 5- vs. 8-, 5- vs. 9-, and 5-vs. 10-month old were significantly different $(\mathrm{z}=$ $-3.061, p=0.002 ; z=-3.059, p=0.002 ; z=$ $-3.059, \mathrm{p}=0.002 ; \mathrm{z}=-3.059, \mathrm{p}=0.002$; and $\mathrm{z}=$ $-3.061, p=0.002$, respectively). The 6- vs 7-, 6- vs. 8-, 6- vs 9-, and 6- vs. 10-month old were significantly different (z $=-2.786, \mathrm{p}=0.005 ; \mathrm{z}=-3.061, \mathrm{p}=0.002 ; \mathrm{z}=-3.061, \mathrm{p}=$ 0.002 ; and $\mathrm{z}=-3.059, \mathrm{p}=0.006$, respectively). The 7 - vs 8-, 7- vs 9-, and 7- vs. 10-month old were significantly different $(z=-2.746, p=0.006 ; z=-3.061, p=0.002$; and $\mathrm{z}=-3.059, \mathrm{p}=0.002$, respectively). The 8- vs 9-, and 8vs 10 -month old were significantly different $(z=-2.981$, $\mathrm{p}=0.003$ and $\mathrm{z}=-3.059, \mathrm{p}=0.002$, respectively). The 9 - vs 10 -month old was significantly different $(z=-3.059$, $\mathrm{p}=0.002$ ) (Table 1). Therefore, the average interval/10 $\mathrm{s}$ were gradually decreased with the advancing age of the male Red-whisker Bulbul. 
TABLE 1. The song characteristics were created by twelve male and two female Red-whiskered Bulbuls aged from 5 to 10 months old

\begin{tabular}{|c|c|c|c|c|c|c|c|}
\hline \multirow[b]{2}{*}{ Gender } & \multirow[b]{2}{*}{ Characteristics } & \multicolumn{6}{|c|}{ Age (months) } \\
\hline & & 5 & 6 & 7 & 8 & 9 & 10 \\
\hline \multirow[t]{5}{*}{ Male } & Time/phrase & $0.21 \pm 0.12$ & $0.39 \pm 0.20$ & $0.44 \pm 0.20$ & $0.55 \pm 0.16$ & $0.65 \pm 0.19$ & $0.74 \pm 0.21$ \\
\hline & Syllables/phrase & $2.47 \pm 0.54$ & $3.16 \pm 0.96$ & $3.04 \pm 0.95$ & $3.52 \pm 0.78$ & $4.03 \pm 0.90$ & $4.37 \pm 0.97$ \\
\hline & Phrases/10 s & $1.67 \pm 0.65$ & $3.58 \pm 1.24$ & $3.75 \pm 1.05$ & $5.25 \pm 0.62$ & $5.58 \pm 0.67$ & $5.92 \pm 0.29$ \\
\hline & Syllables/10 s & $15.33 \pm 0.93^{\mathrm{A}}$ & $17.92 \pm 0.96^{\mathrm{AB}}$ & $19.25 \pm 0.52^{\mathrm{aBC}}$ & $21.75 \pm 0.56^{\mathrm{abcD}}$ & $23.83 \pm 1.01^{\mathrm{abcdE}}$ & $25.83 \pm 1.02^{\text {abcde }}$ \\
\hline & Intervals $/ 10 \mathrm{~s}$ & $7.00 \pm 0.09^{\mathrm{A}}$ & $6.37 \pm 0.12^{\mathrm{aB}}$ & $6.16 \pm 0.13^{\mathrm{abC}}$ & $5.76 \pm 0.12^{\mathrm{abcD}}$ & $5.31 \pm 0.18^{\mathrm{abcdE}}$ & $4.81 \pm 0.22^{\mathrm{abcde}}$ \\
\hline \multirow[t]{5}{*}{ Female } & Time/phrase & $0.20 \pm 0.10$ & $0.25 \pm 0.13$ & $0.29 \pm 0.12$ & $0.37 \pm 0.13$ & $0.36 \pm 0.14$ & $0.43 \pm 0.16$ \\
\hline & Syllables/phrase & $2.00 \pm 0.00$ & $2.36 \pm 0.67$ & $2.40 \pm 0.73$ & $2.89 \pm 0.90$ & $2.88 \pm 0.80$ & $2.88 \pm 0.80$ \\
\hline & Phrases/10 s & & $1.00 \pm 1.00$ & $1.33 \pm 0.57$ & $3.33 \pm 0.57$ & $3.33 \pm 0.57$ & $3.12 \pm 0.78$ \\
\hline & Syllables/10 s & $12.00 \pm 2.00$ & $13.00 \pm 1.73$ & $13.67 \pm 1.53$ & $17.33 \pm 1.53$ & $16.33 \pm 1.15$ & $18.33 \pm 0.57$ \\
\hline & Intervals $/ 10 \mathrm{~s}$ & $7.42 \pm 0.14$ & $7.21 \pm 0.20$ & $7.21 \pm 0.13$ & $6.83 \pm 0.12$ & $6.59 \pm 0.23$ & $6.45 \pm 0.18$ \\
\hline
\end{tabular}

Note: $\mathrm{Aa}, \mathrm{Bb}, \mathrm{Cc}, \mathrm{Dd}$, Ee, uppercase, and lowercase of the same alphabets demonstrated significant differences between ages ( $\mathrm{p}<0.05)$. Only male syllables $/ 10 \mathrm{~s}$ and intervals $/ 10 \mathrm{~s}$ had been statistically analysed. No statistical data analysis on female due to limited data

TOTAL TESTOSTERONE OF THE MALE AND FEMALE REDWHISKERED BULBULS AGED 5-10 MONTHS

It was found that the average levels of total testosterone of the male Red-whiskered Bulbul tended to be markedly increased and much more than those of the female at every age (Figure 3). The average amount of total testosterone of the male Red-whiskered Bulbul aged 5, 6, 7, 8, 9 and 10 months were $0.08 \pm 0.00,0.29 \pm 0.06,0.49 \pm 0.17$, $2.65 \pm 0.52,2.85 \pm 0.49$ and $4.47 \pm 0.46 \mathrm{ng} / \mathrm{g}$ dry faeces, respectively. The average amount of total testosterone levels of the female Red-whiskered Bulbul aged 5, 6, 7, 8,9 and 10 months were $0.05 \pm 0.01,0.07 \pm 0.01,0.09 \pm$ $0.01,0.11 \pm 0.03,0.14 . \pm 0.04$; and $0.20 \pm 0.03 \mathrm{ng} / \mathrm{g}$ dry faeces, respectively.

The mean rank of the total testosterone levels was significantly different among the age groups (Friedman test, $\left.\chi^{2}=51.478, \mathrm{p}=0.000\right)$. A comparison between each two age group (Wilcoxon signed-rank test) was as following: the 5- vs. 6-, 5- vs. 7-, 5- vs. 8-, 5- vs. 9-, and 5- vs. 10-month old were significantly different $(\mathrm{z}=-3.065, \mathrm{p}=0.002 ; \mathrm{z}=-2.121, \mathrm{p}=0.034$; $\mathrm{z}=-2.512, \mathrm{p}=0.012 ; \mathrm{z}=-2.747, \mathrm{p}=0.006$; and $\mathrm{z}=-3.061, \mathrm{p}=0.002$, respectively). The
6- vs 7-, 6- vs. 8-, 6- vs 9-, and 6- vs. 10-month old were significantly different $(z=-2.312$, $\mathrm{p}=0.021 ; \mathrm{z}=-3.061, \mathrm{p}=0.002 ; \mathrm{z}=-3.061, \mathrm{p}=0.002$; and $\mathrm{z}=-3.061, \mathrm{p}=0.002$, respectively). The 7- vs 8-, 7- vs 9-, and 7- vs. 10-month old were significantly different $(\mathrm{z}=$ $-3.061, p=0.002 ; z=-2.941, p=0.003$; and $z=-3.061$, $\mathrm{p}=0.002$, respectively). The 8 - vs 9 - month old was not significantly different $(\mathrm{z}=-0.628, \mathrm{p}=0.530)$, and 8 - vs 10 -month old was significantly different $(\mathrm{z}=-2.354, \mathrm{p}=$ $0.019)$. The 9 - vs 10-month old was significantly different $(\mathrm{z}=-3.061, \mathrm{p}=0.002)$. The amount of testosterone in the male Red-whiskered Bulbuls increased continually with advancing age, especially at the ages of 8-10 months.

\section{CORRELATIONS BETWEEN TOTAL TESTOSTERONE AND SONG TYPES OF THE MALE RED-WHISKERED BULBULS AGED 5-10 MONTHS}

Total testosterone levels and the number of syllables/10 s demonstrated a positive correlation $(\mathrm{r}=0.68, \mathrm{p}=0.01)$. The levels of total testosterone were increased, consequently, the number of syllables/10 s was increased (Figure 4).

Total testosterone and the intervals $/ 10 \mathrm{~s}$ of male Redwhiskered Bulbuls had a negative correlation $(\mathrm{r}=-0.69$, 
$\mathrm{p}=0.01)$. When the level of total testosterone of male Red-whiskered Bulbul was increased, the interval was decreased (Figure 5).

It was found that the number of syllables in $10 \mathrm{~s}$ was negatively correlated with the interval between a phrase in $10 \mathrm{~s}(\mathrm{r}=-0.93, \mathrm{p}=0.01)$. It showed that when the male Red-whiskered Bulbul created more syllables, the interval between phrases decreased. Therefore, the adult male Redwhiskered Bulbul could create the song with more syllables while the interval between phrases decreased (Figure 6).

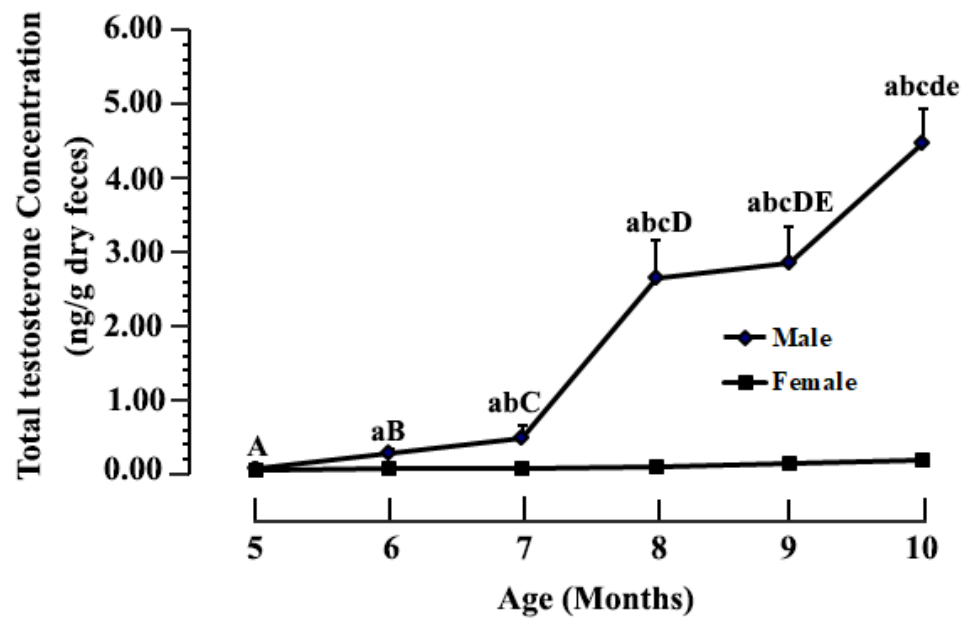

FIGURE 3. The amount of total testosterone (mean $\pm \mathrm{SD}$ ) of the male Red-whiskered Bulbul (Pycnonotus jocosus) $(\mathrm{n}=12)$ and female $(\mathrm{n}=2)$ aged 5-10 months

Note: $\mathrm{Aa}, \mathrm{Bb}, \mathrm{Cc}, \mathrm{Dd}, \mathrm{Ee}$, uppercase, and lowercase of the same alphabets demonstrated significant differences between ages $(\mathrm{p}<0.05)$. We did not analyze statistical data in female birds due to limited data

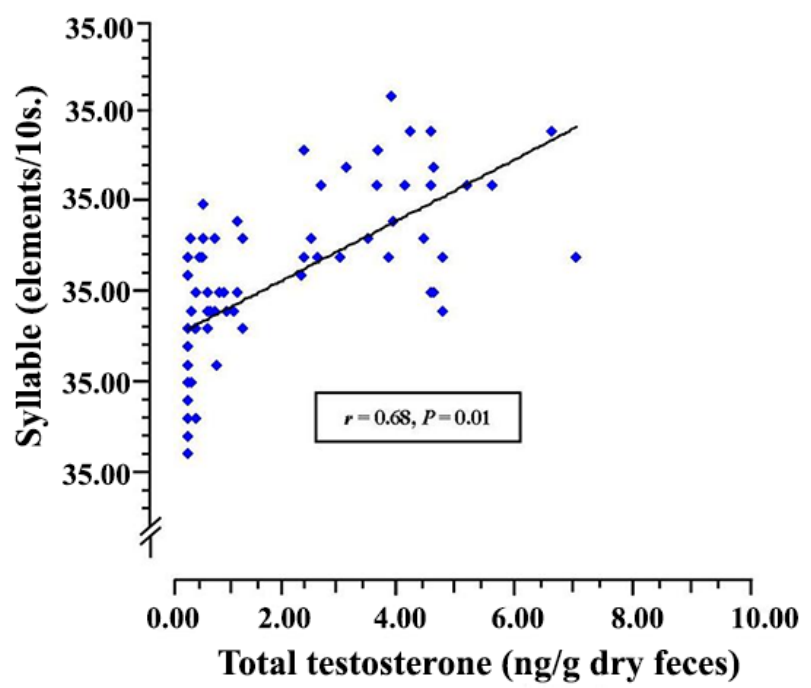

FIGURE 4. Correlation between total testosterone and the number of syllables/10 s of male Red-whiskered Bulbuls aged 5-10 months 


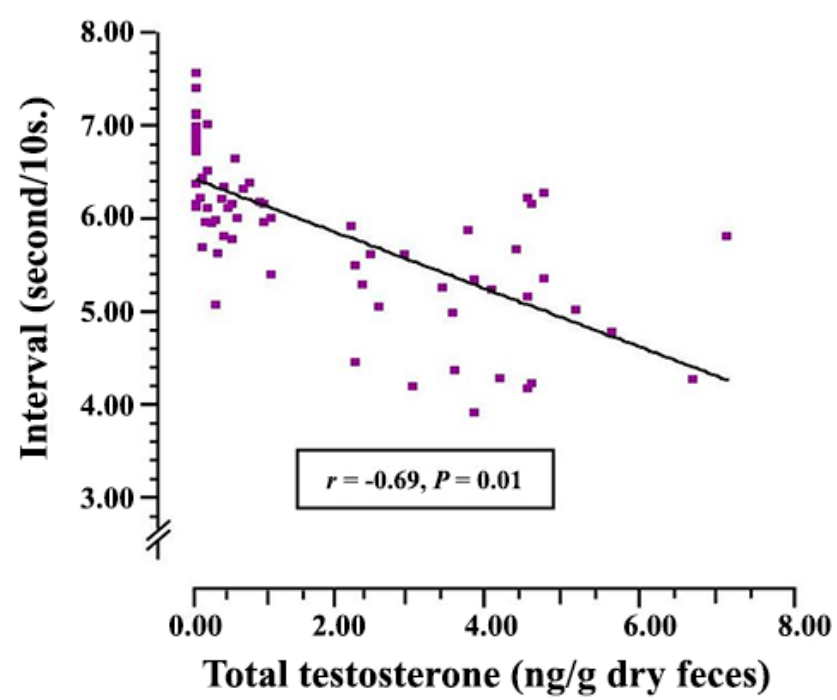

FIGURE 5. Correlation between the total testosterone level and the interval in $10 \mathrm{~s}$ of the male Red-whiskered Bulbul aged 5-10 months

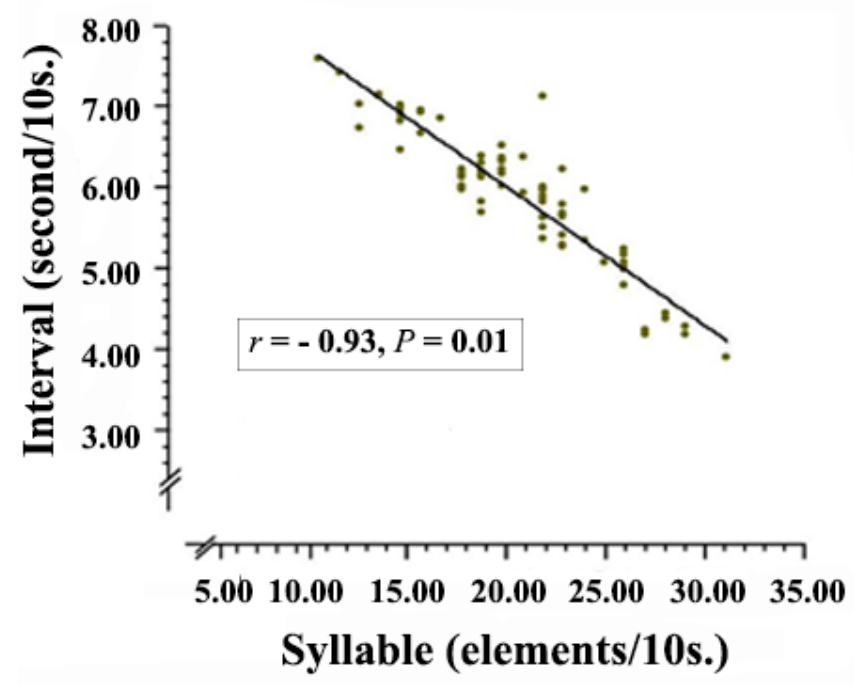

FIGURE 6. The relationship between the number of syllables and the intervals/10 s of the male Red-whiskered Bulbul aged 5-10 months

\section{DISCUSSION}

From the study of sonogram patterns, it was found that Red-whiskered Bulbuls aged 5-10 months developed the number of syllables with the advancing age, namely 15 , $18,19,22,24$, and 26 syllables/10 s, respectively. Song patterns produced by the male Red-whiskered Bulbul aged from 8 to 10 months resembled the sonogram prototype. This was consistent with the studies of Marler and Peter (1987) which found that sparrow at the age of 8 months old could learn the song from the master song. Alternatively, the age was when that young sparrow was sensitive to learning singing a song. 
Kumar (2004) found that the Red-vented Bulbul ( $P$. cafer) created a song with a phrase frequency of 0.98-6.36 $\mathrm{kHz}$ and a phrase duration of 0.65-1.2 $\mathrm{s}$ (mean $\pm \mathrm{SD}, 0.79$ $\pm 0.08)$. In this study, the male Red-whiskered Bulbul aged 8-10 months produced phrase frequency and phrase duration of $1.50-5.18 \mathrm{kHz}$ and $0.48-1.31 \mathrm{~s}$ (mean $\pm \mathrm{SD}$, $0.74 \pm 0.23)$, respectively, consisting of 3-6 syllables/ phrase (mean $\pm \mathrm{SD}, 4.37 \pm 0.97$ ) in the male Red-whiskered Bulbul but consisting of 1-4 syllables/phrase (mean \pm $\mathrm{SD}, 3.12 \pm 0.78$ ) in the female Red-whiskered Bulbul. The phrase frequency of the Red-whiskered Bulbul was narrower than that of the Red-vented Bulbul but the phrase duration of the Red-whiskered Bulbul was longer than that of the Red-vented Bulbul. Carleton and Owre (1975) found that the Red-whiskered Bulbul in Florida which is imported from foreign countries and propagated quickly in nature has a similar song as the Red-vented Bulbul habituated in a common colony.

The male Red-whiskered Bulbul aged 8-10-monthold had the song pattern consisting of the most variety of song phrases. However, some phrases were similar to the song prototype and there were only some syllables in one phrase that resembled the song prototype. Podos et al. (1992) also stated that from recording songs of 200-300 samples of twelve adult male Song Sparrows (Melospiza melodia), it was found that very few songs were similar to the song prototype as each such Song Sparrow established much more variation in song patterns. Smith et al. (1997) found that changes in the testosterone levels resulted in the changes in the song structure of the Song Sparrow in a positive manner. Additionally, the season could cause changes in the concentration of plasma testosterone.

According to the study of Arnold (1997) in the adult Zebra Finch, the alterations in testosterone seasonally corresponded well with the singing of the Zebra Finch. Additionally, he also located the testosterone receptors in many parts of the nervous system, including hyperstriatum ventrale pars caudale ( $\mathrm{HVc}$ ) and the magnocellular nucleus of the anterior neostriatum (MAN) which are involved in memorizing and then developing the songs. According to a study by Brenowitz (1997), it was found that the HVc and the MAN in female birds were smaller than those of male birds, resulting in the more complexity of the song pattern in males than that of the females. In this study, we also found that the song patterns of the female Redwhiskered Bulbul had a variety of fewer phrases with only 1-4 short syllables per phrase and the low level of total testosterone throughout this experiment. From this study, male Red-whiskered Bulbul can develop different varieties of song phrases by adapting from the song prototype that led to fluctuations in the sound pattern song. Concurrently, such song learning behaviour corresponded well with the marked increase in total testosterone.

\section{LIMITATION OF STUDY}

Ideally, there should be some birds that are not being provoked with the broadcasting of taped calls to serve as a control and to ensure that the results observed are valid. However, the usage of the song prototype is reasonably appropriate in this study as it had been conducted in the closed air-conditioning laboratory room without any noise disturbance outside and had the efficiency to manipulate all the experiments.

\section{CONCLUSION}

The male sex steroid hormone, testosterone, positively correlated to a variety of the song characteristics created by the male Red-whiskered Bulbuls. It has a pronounced effect on the development and function of the song controlling circuits and modulates the production of songs in an age-dependent manner.

\section{ACKNOWLEDGEMENTS}

We thank the anonymous reviewer and the responsible editor for critical and constructive comments on an earlier version of the manuscript and the Department of Zoology of Kasetsart University for financial support.

\section{REFERENCES}

Arnold, A.P. 1997. Sexual differentiation of the zebra finch song system: Positive evidence, negative evidence, null hypothesis, and a paradigm shift. J. Neurobiol. 33(5): 572-584.

Bohner, J., Chaiken, M.L., Ball, G.F. \& Marler, P. 1990. Song acquisition in photosensitive and photorefractory male European Starlings. Horm. Behav. 24(4): 582-594.

Bottjer, S.W. \& Johnson, F. 1997. Circuits, hormones and learning: Vocal behavior in songbirds. J. Neurobiol. 33(5): 602-618.

Brenowitz, E.A. 1997. Comparative approaches to the avian song system. J. Neurobiol. 33(5): 517-531.

Brenowitz, E.A., Margoliash, D. \& Nordeen, K.W. 1997. An Introduction to Bird Song and the Avian Song System. Washington: John Wiley \& Sons, Inc. p. 495.

Carleton, A.R. \& Owre, O.T. 1975. The Red-Whiskered Bulbul in Florida: 1960-71. The Auk 92: 40-57.

Catchpole, C.K. 1979. Vocal Communication in Bird. London: Edward Arnold. p. 115.

Catchpole, C.K. \& Slater, P.J.B. 1995. Bird Song: Biological Themes and Variation. 2nd ed. New York, London: Cambridge University Press. p. 38. 
Cockrem, J. \& Rounce, J.R. 1995. Faecal measurements of oestradiol and testosterone allow the noninvasive estimation of plasma steroid concentrations in the domestic fowl. $\mathrm{Br}$. Poult. Sci. 35(3): 433-443.

Galeotti, P., Saino, N., Sacchi, R. \& Moller, A.P. 1997. Song correlates with social context, testosterone and body condition in male barn swallows. Anim. Behav. 53(4): 687-700.

Griffiths, R. \& Tiwari, B. 1995. Sex of the last wild Spix's macaw. Nature 375: 454.

Jarvis, E.D. 2004. Learned birdsong and the neurobiology of human language. Ann. N. Y. Acad. Sci. 1016: 749-777.

Khananurak, M. 2006. Zebra Dove and Red-Whiskered Bulbul. Odian Store, Bangkok.

Kumar, A. 2004. Acoustic communication in the Red-Vented Bulbul Pycnonotus cafer. An. Acad. Bras. Cienc. 76(2): 350-358.

Marler, P. 1997. Three models of song learning: Evidence from behavior. J. Neurobiol. 33(5): 501-516.

Marler, P. \& Peters, S. 1987. A sensitive period for song acquisition in the Song Sparrow: A case of age-limited learning. Ethology 76(2): 89-100.

Podos, J., Peters, S., Rudnicky, T., Marler, P. \& Nowicki, S. 1992. The organization of song repertoires in Song Sparrow: Themes and variations. Ethology 90: 89-106.

Schlinger, B.A. 1997. Sex steroids and their actions on the birdsong system. J. Neurobiol. 33(5): 619-631.

Sitasuwan, N. 1993. Ornithology in fieldwork. Department of Biology. Faculty of Science, Chiangmai University, Chiangmai (Unpublished).
Smith, G.T., Brenowitz, E.A., Beecher, M.D. \& Wingfield, J.C. 1997. Seasonal changes in testosterone, neural attributes of song control nuclei, and song structure in wild songbirds. $J$. Neurosci. 17(15): 6001-6010.

Panas Tumkiratiwong \& Darika Manathamkamon Department of Zoology

Faculty of Science

Kasetsart University

Bangkok 10900

Thailand

Rattanawat Chaiyarat

Faculty of Environment and Resource Studies

Mahidol University

Salaya Campus

Nakhon Pathom 73170

Thailand

Kan Khoomsab*

Education Science Program

Faculty of Science and Technology

Phetchabun Rajabhat University

Phetchabun 67000

Thailand

*Corresponding author; email: topkan13@hotmail.com

Received: 17 June 2020

Accepted: 2 October 2020 